\title{
STUDI EMPIRIS TENTANG PENGAWASAN KERJA, PENGALAMAN KERJA, DAN KEMAMPUAN KERJA SERTA PENGARUHNYA TERHADAP MOTIVASI BERPRESTASI KARYAWAN
}

\author{
Rahayu Mardikaningsih", Samsul Arifin ${ }^{2}$ \\ Universitas Mayjen Sungkono \\ Email : rahayumardikaningsih@gmail.com; Samsularifin.unimas@gmail.com
}

\begin{abstract}
Human assets as one of the elements of manufacturing are the riding pressure of each organisation. They have a main function in understanding the organisation's goals. Companies ought to constantly inspire them to offer the excellent paintings effects in order that organisation sports aren't hampered consistent with their workload and responsibilities. Good paintings effects are primarily based totally at the lifestyles of a cause for fulfillment and there are numerous variables that have effect on this. This studies targets to research and decide the impact of labor supervision, paintings revel in, and paintings cappotential on fulfillment motivation. This quantitative studies takes the populace targeted on personnel who paintings withinside the manufacturing phase of a multinational organisation in Sidoarjo. Respondents on this observe have been a hundred and twenty respondents. The analytical device used, particularly SPSS model 25 program. The sampling method on this observe the usage of purposive sampling method. The analytical device used is more than one linear regression analysis. The effects confirmed that each one hypotheses have been demonstrated correct. Work supervision has a massive effective impact on fulfillment motivation. Work revel in and paintings cappotential even have a massive have effect on fulfillment motivation. The 3 of them offer a massive impact concurrently on fulfillment motivation.
\end{abstract}

Keywords: job supervision, work experience, work ability, achievement motivation.

\section{Pendahuluan}

Karyawan yang mempunyai peran di perusahaan merupakan sumber daya organisasi yang humanis dan menjadi faktor utama dari seluruh kegiataan operasional perusahaan. Bentuk hubungan antara karyawan dan perusahaan adalah simbiosis mutualisme yang seharusnya saling memberikan manfaat bagi kedua belah pihak. Untuk itu perusahaan memerlukan karyawan untuk setiap kegiatan operasional dan karyawan memerlukan perusahaan untuk mendapatkan setiap bentuk 
kompenasi untuk memenuhi kebutuhannya (Hutomo, 2011). Adanya keterikatan ini menyebabkan kepentingan masing-masing harus diperhatikan satu sama lain.

Kegiatan operasional perusahaan terjadi di setiap departemen secara rutin dan melibatkan prosedur dan personil yang harus terhubung dengan tujuan perusahaan agar semua berjalan secara terarah dan terukur (Khasanah et al., 2010). Bagi perusahaan skala besar yang ditandai dengan jumlah karyawan yang banyak diperlukan sistem pengawasan kerja yang tepat (Pearce et al., 2013). Efektivitas harus tercapai melalui pengawasan kerja dari setiap pimpinan tingkat lini pertama di setiap departemen. Pengawasan yang sistematis, objektif dan berkesinambungan akan memberikan kontribusi bagi perusahaan serta memberikan kontribusi bagi pengembangan unsur manusia di perusahaan karena setiap kerja dan hasilnya terpantau dengan seksama (Enaigbe, 2009). Pengawasan menjadi pengaturan standar seperti standar kualitas atau capaian jumlah produk yang dihasilkan; pemeriksaan untuk menilai kinerja nyata dari karyawan serta disesuaikan dengan standar kerja; mengambil tindakan untuk memperbaiki kesalahan saat melakukan tugas (Wahyudi et al., 2006; Dessler, 2009). Pengawasan kerja menjadi stimulus bagi produktivitas dan motif berprestasi dikarenakan adanya umpan balik secara terarah bagi setiap hasil kerja dari karyawan (Putra et al., 2017). Bagi karyawan yang telah mempunyai pengalaman kerja dan bersikap profesional maka pengawasan kerja menjadi hal yang lumrah untuk dilakukan secara berkelanjutan (Sinambela et al., 2020). Mereka berpikir pengawasan perlu dilakukan sebagai perwujudan dari pengendalian mutu kerja dan pemenuhan standar kerja sehingga umpan balik tersebut menjadi evaluasi bagi masing-masing karyawan yang menjalankan kewajibannya (Werdati et al., 2020).

Pengalaman kerja menunjukkan level seseorang menguasai pekerjaannya yang ditunjukkan dari tingkat pengetahuan serta keterampilannya untuk menyelesaikan tugas (Mardikaningsih et al., 2017). Pengalaman kerja dinilai dari ragam pekerjaan yang dikuasai oleh karyawan (Hariani et al., 2019). Selain itu juga berdasarkan dari masa kerja. Menurut Robbins dan Judge (2008), pengalaman kerja terbentuk dari keterampilan dan pengetahuan selama bekerja. Karyawan yang memiliki pengalaman telah mengenal ragam masalah yang pernah 
dihadapinya dan cara menghadapinya. Mereka telah memiliki kemampuan kerja yang lebih baik dibandingkan karyawan lain yang belum mempunyai pengalaman kerja tetapi hal itu terjadi dengan asumsi mereka menjalani pekerjaannya sesuai dengan kemampuan kerja dan melakukan proses pembelajaran dari waktu ke waktu. Beberapa studi telah menunjukkan bahwa pengalaman kerja memiliki relevansi dengan komitmen organisasi, kinerja karyawan dan motivasi berprestasi (Wagner et al., 1985; Handoko, 2004; Hariani et al., 2019; Darmawan et al., 2019). Oleh sebab itu, perusahaan sering lebih tertarik merekrut karyawan yang berpengalaman tertuju pada pengisian jabatan tertentu.

Menurut Al Hakim et al. (2019), kemampuan kerja merupakan perwujudan dari kapasitas seseorang untuk menjalankan beragam tugas terkait pekerjaannya. Kemampuan kerja menjadi bahan dasar dari terbentuknya kinerja karyawan. Motivasi berprestasi yang dimiliki karyawan juga menjadi berarti bila didukung oleh kemampuan kerja (Schuler et al., 2010). Karyawan memiliki motivasi merupakan harapan dari hasil kinerja karyawan untuk dapat mengembangkan karirinya dengan prestasi yang dimiliki (Sinambela, 2018). Motivasi berprestasi sebagai bagian dari bentuk motivasi yang digagas oleh David Mc Clelland. Alasan untuk berprestasi adalah motivasi dalam diri untuk menghasilkan hasil kerja sesuai yang diharapkan pimpinan dan standar kerja (Elliot et al., 2000). Hal ini mungkin diperjuangkan demi mencapai penghargaan kepada diri sendiri. Untuk mewujudkan hal tersebut, karyawan harus memiliki keinginan dan motif yang kuat.

Setiap karyawan mempunyai motif berprestasi yang tidak sama sesuai dengan kekuatan dan kebutuhan terhadap prestasi tersebut (Jagacinski dan Duda, 2001). Besarnya motivasi juga penting untuk karyawan. Masalah-masalah berbeda dapat diperhitungkan untuk setiap tugas dan lebih sering dilakukan dengan tidak sadar. Beberapa variabel akan menjadi faktor penentu seseorang termotivasi untuk melaksanakan atau menghindari tugas. Menurut Atkinson dan Feather (1966), seseorang yang memiliki motivasi untuk mempunyai prestasi akan berperilaku yang mengarah kepada perilaku yang positif. Seseorang yang memiliki motivasi untuk tidak gagal, perilakunya akan mengarahkan pada hal-hal yang memiliki kemungkinan tidak diinginkan atau mengarah pada kegagalan. Motif mana yang 
dipilih seseorang bergantung pada kekuatan relatif dari motif pencapaian tersebut untuk mencapai kesuksesan, atau untuk menghindari kegagalan (Darmawan, 2019). Adanya motivasi berprestasi mengarahkan kepada pencapaian keberhasilan.

Semua karyawan dipengaruhi oleh kebutuhan untuk berprestasi (Santosa, 2002; Djati, 2005). Itu menyebabkan mereka ingin sukses dalam apa yang mereka upayakan namun setiap karyawan dipengaruhi oleh derajat yang berbeda (Andayani, 2010; Putra, 2019). Bagi beberapa karyawan, keinginan untuk berprestasi mengalahkan faktor-faktor lain yang dapat menyebabkan kegagalan, seperti; kurangnya keterampilan, kurangnya pengalaman, kurangnya kemampuan, atau kurangnya waktu. Individu melakukan apa pun untuk mengatasi atau menghilangkan bentuk-bentuk kemunduran ini dengan adanya motivasi berprestasi (Atkinson, 1974).

Berdasarkan keterangan yang diperoleh peneliti akan melakukan penelitian dengan judul Studi Empiris tentang Pengawasan Kerja, Pengalaman Kerja, dan Kemampuan Kerja Serta Pengaruhnya terhadap Motivasi Berprestasi Karyawan. Penelitian ini dilaksanakan pada salah satu perusahaan multinasional di Kabupaten Sidoarjo. Rumusan penelitian ini adalah (1) apakah pengawasan kerja memiliki peran secara nyata terhadap motivasi berprestasi karyawan? (2) apakah pengalaman kerja memiliki peran secara nyata terhadap motivasi berprestasi karyawan? (3) apakah kemampuan kerja memiliki peran secara nyata terhadap motivasi berprestasi karyawan? (4) apakah pengawasan kerja, pengalaman kerja, dan kemampuan kerja memiliki peran nyata secara simultan terhadap motivasi berprestasi karyawan?

\section{Tinjauan Pustaka}

\subsection{Pengawasan Kerja}

Kegiatan pengawasan memiliki ruang lingkup untuk mengarahkan serta mengawasi. Hal tersebut menjadi untuk memastikan semua pekerjaan dilakukan sesuai dengan standar (Mathis dan Jackson, 2006). Pengawasan merupakan kegiatan untuk mengamati proses kerja dan perilaku karyawan (Sjamsi, 2004). Hal yang diamati akan dibandingkan dengan standar ketentuan dan selanjutnya dijadikan masukan di penilaian kinerja karyawan (Johnson, 2000). Pengawas pun berperan 
untuk mengoleksi informasi untuk umpan balik penilaian kinerja yang akan ditunjukkan kepada karyawan (Putra et al., 2017). Chiovere (1995) menyatakan bahwa pengawasan melibatkan penilaian implementasi kebijakan yang tepat, koreksi kelemahan yang teridentifikasi, arah dan pengarahan untuk pencapaian tujuan. Pearce et al. (2013) mengembangkan lima indikator untuk pengukuran efektivitas pengawasan, yaitu batasan, komitmen pengawas, hasil subjek pengawasan, pengaruh eksternal, dan temuan pengawas. Indikator tersebut diterjemahkan menjadi menentukan ukuran; mengadakan penilaian terhadap tugas; perbandingan standar; pengarahan dan tindakan korektif terhadap dari segala penyimpangan.

\subsection{Pengalaman Kerja}

Ukuran mengenai masa kerja yang dilalui individu untuk menjalani tugas atau pekerjaannya mengarah kepada ruang lingkup pengalaman kerja (Foster, 2001). Darmawan et al. (2019) menyatakan pengalaman kerja hanya diperoleh di tempat kerja dan diukur dari masa kerja, pengetahuan tentang pekerjaan serta keterampilan. Pengalaman kerja menjadi indikasi dari kinerja seorang pekerja. Semakin beragam pengalaman seseorang seharusnya menunjukkan hasil kerja yang baik pada tingkatan tertentu (Schmidt et al., 1986; 1988). Pengalaman kerja diukur melalui berapa lama seseorang telah bekerja atau hal itu dilihat dari masa kerjanya. Selain itu pengalaman kerja juga dipantau melalui seberapa banyak variasi pekerjaan yang telah dilakukan seseorang termasuk bentuk tanggung jawab dan tugasnya. Menurut Schmidt et al. (1988), pengalaman kerja seseorang dapat ditinjau dari (1) penguasaan terhadap pekerjaan; (2) pengetahuan dan keterampilan kerja (3) masa kerja.

\subsection{Kemampuan Kerja}

Darmawan (2013) menyatakan bahwa kemampuan kerja sebagai proses yang kompleks dan dinamis, yang mencerminkan interaksi antara kemampuan fisik dan mental (karakteristik individu), kondisi kerja, kemampuan fungsional karyawan, status kesehatan karyawan serta penilaian individu terhadap posisi mereka di organisasi. Menurut Al Hakim et al. (2019), kemampuan kerja merupakan perwujudan dari kapasitas seseorang untuk menjalankan beragam tugas terkait 
pekerjaannya. Menurut Ilmarinen (2004), kemampuan kerja diartikan sebagai kemampuan untuk melakukan tugas berdasarkan kondisi mental dan fisik dan kebutuhan pekerjaan dan juga kapasitas dan kemampuan individu dalam kaitannya dengan kebutuhan fisik dan psikologis pekerjaan. Gibson et al. (2009) menyatakan bahwa karakteristik sejak lahir maupun yang menjadi pengetahuan saat melakukan proses pembelajaran sehingga seseorang mampu mengerjakan tugas dan tanggung jawabnya merupakan cakupan dari kemampuan kerja. Indikator kemampuan kerja menurut Gibson et al. (2009) yaitu: (1) keterampilan teknis (2) keterampilan konseptual (3) keterampilan berinteraksi.

\subsection{Motivasi berprestasi}

Motivasi berprestasi adalah sebagai dasar kemampuan dan daya tahan yang harus dimiliki untuk mencapai suatu tujuan dalam waktu yang telah ditentukan Motivasi dinilai sebagai kekuatan dan daya tahan yang dibutuhkan untuk mencapai sesuatu dalam waktu yang telah ditentukan, dan motivasi berkaitan dengan motivasi tindakan dan tujuan (Darmawan, 2013; Sinambela, 2014). Sparrow (1998) menyatakan bahwa motivasi mempunyai pengaruh atas penciptaan mental seseorang. Motivasi sendiri terdiri dari kerja yang aman, seberapa pentingnya pekerjaan, kinerja yang baik, peluang dan saluran promosi (Mardikaningsih, 2014). Karyawan yang memiliki motivasi besar akan mempunyai semangat timggi untuk terlibat dalam segala kegiatan dan akan mempunyai inovasi dengan cara berpikir ke depan dan akan bertanggung jawab akan dirinya sendiri dibandingkan karyawan yang tidak memiliki semangat untuk melakukan prestasi atau memiliki semangat tapi dalam sekala rendah (McClelland et al., 1987). Lebih lanjut Mc Clelland menyatakan keinginan seseorang sehingga memunculkan dorongan untuk mencapai keunggulan atau setidaknya berusaha untuk mencapai standar tertentu telah menunjukkan adanya motivasi berprestasi. Beberapa ahli mengutarakan beberapa definisi tentang motivasi, yaitu (1) motivasi berprestasi dapat dijabarkan sebagai keinginan yang ada pada karyawan untuk melakukan hal terbaik yang ada pada diri mereka agar tujuannya tercapai sehingga mereka mendapatkan prestasi yang mereka (Rabideau, 2005; Ghasemi, et al., 2011; Weseley dan McEntarffer, 2010); (2) Atkinson dan 
Feather (1966) mendefinisikan motivasi berprestasi sebagai perpaduan indikasi kepribadian yang cenderung menjauhi kegagalan dan mendekati keberhasilan; (3) Beigge dan Hunt (1980) berpendapat motivasi berprestasi merupakan keinginan melakukan pekerjaan dengan tekun dan totalitas sehingga dapat mencapai target; (5) Dave dan Anand (1979) mengatakan bahwa motivasi berprestasi adalah harapan karyawan untuk melakukan yang terbaik secara berbeda-beda kepada beberapa orang dengan tolak ukur yang lebih tinggi. Helmreich dan Spence (1978) menyatakan ada empat indikator motivasi berprestasi, yaitu (1) penguasaan kebutuhan; (2) orientasi kerja; (3) kompetisi; (4) pribadi yang tidak peduli.

\subsection{Rerangka Konseptual}

Pengaruh pengawasan kerja, pengalaman kerja, dan kemampuan kerja secara parsial dan secara simultan terhadap motivasi berprestasi. Hal tersebut yang akan diteliti dan penelitian ini berdasarkan penelitian sebelumnya bahwa (1) pengawasan kerja memiliki peran secara nyata terhadap motivasi berprestasi karyawan (Ekowati, 2012); (2) pengalaman kerja memiliki peran secara nyata terhadap motivasi berprestasi karyawan (Handayani 2010); (3) kemampuan kerja memiliki peran secara nyata terhadap motivasi berprestasi karyawan (Apriani, 2009).

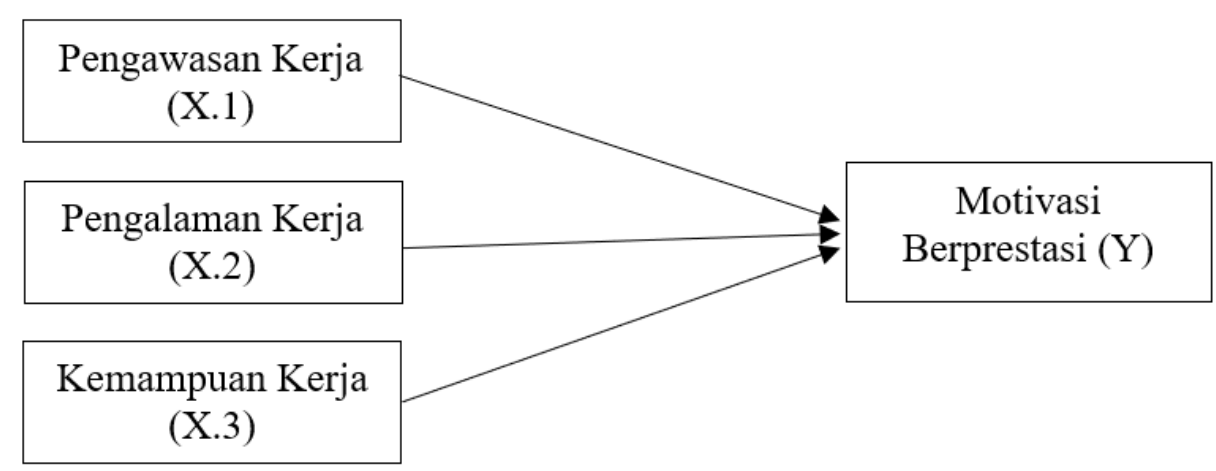

Gambar 1. Rerangka Konsep Penelitian Sumber : diolah oleh peneliti, 2021

Berdasarkan rerangka konseptual yang telah diuraikan sebelumnya, maka hipotesis dalam penelitian ini adalah (1) pengawasan kerja memiliki peran secara nyata terhadap motivasi berprestasi karyawan; (2) pengalaman kerja memiliki peran 
secara nyata terhadap motivasi berprestasi karyawan; (3) kemampuan kerja memiliki peran secara nyata terhadap motivasi berprestasi karyawan; (4) pengawasan kerja, pengalaman kerja, dan kemampuan kerja memiliki peran nyata secara simultan terhadap motivasi berprestasi karyawan.

\section{Metode Penelitian}

Pendekatan deskriptif kuantitatif dilakukan pada penelitian ini sebab hasil penelitian akan dijabarkan dalam bentuk angka dan dijelaskan memakai deskripsi. Responden adalah karyawan di bagian produksi pada salah satu perusahaan multi nasional yang lokasi di Sidoarjo. Data yang didapat merupakan hasil dari penyebaran kuesioner kepada responden. Penelitian ini memakai Teknik purposive sampling. Total responden yang didapat sebanyak 120 responden. Varibel yang ada pada penelitian ini, yaitu pengawasan kerja (X.1), pengalaman kerja (X.2), kemampuan kerja (X.3), dan motivasi berprestasi (Y). Skala likert akan digunakan untuk penelitian ini dengan rentang nilai 1-8 (Sangat Tidak Setuju Sekali=1 hingga Sangat Setuju sekali hingga=8). Teknik analisis liner berganda pada penelitian ini dengan menggunakan variabel pengawasan kerja dan pengalaman kerja dan motivasi berprestasi. Langkah selanjutnya adalah dilakukan uji reliabilitas dan uji validitas. Uji asumsi klasik meliputi uji multikolonieritas, uji heterokedastisitas, uji autokorelasi dan uji normalitas. Selanjutnya dilakukan uji kelayakan lebih dalam dengan menggunakan uji hipotesis diantaranya uji secara parsial (uji t) dan uji secara simultan (uji F).

\section{Hasil Dan Pembahasan}

\subsection{Profil responden}

Karyawan produksi sebanyak 120 orang akan menjadi objek pada penelitian ini. Pada penelitian ini terdapat semua responden berjenis kelamin wanita. Berikut penyajian mengenai profil responden. 
Tabel 1. Profil Responden Berdasarkan Usia

\begin{tabular}{ccc}
\hline Usia & Jumlah & Persentase \\
\hline $18-20$ tahun & 38 & $31,66 \%$ \\
\hline $21-25$ tahun & 62 & $51,66 \%$ \\
\hline $26-30$ tahun & 17 & $14,17 \%$ \\
\hline $31-35$ tahun & 2 & $1,67 \%$ \\
\hline $36-40$ tahun & 1 & $0,08 \%$ \\
\hline Jumlah & 120 & $100 \%$ \\
\hline
\end{tabular}

Sumber : output SPSS, diolah penulis 2020

Berdasarkan Tabel 1 tentang pembagian usia responden pada penelitian yang mendominasi adalah usia 18-20 tahun sebanyak 31,66\% dan usia 21-25 tahun sebanyak 51,66\%. Usia yang mendominasi termasuk usia produktif. Hal ini dikarenakan perusahaan telah mempertimbangkan pada usia tersebut, karyawan di bagian produksi memiliki tingkat ketelitian yang tinggi untuk menjaga kualitas produk.

Tabel 2. Profil Responden Berdasarkan Masa Kerja

\begin{tabular}{ccc}
\hline Usia & Jumlah & Persentase \\
\hline$<1$ tahun & 13 & $10,83 \%$ \\
\hline $1-3$ tahun & 48 & $40,00 \%$ \\
\hline $4-5$ tahun & 43 & $35,83 \%$ \\
\hline $5-10$ tahun & 11 & $9,16 \%$ \\
\hline$>10$ tahun & 5 & $4,16 \%$ \\
\hline Jumlah & 120 & $100 \%$ \\
\hline
\end{tabular}

Sumber : output SPSS, diolah penulis 2020

Berdasarkan masa kerja seperti pada Tabel 2, profil responden didominasi di rentang 1 sampai 5 tahun dengan total sebesar 91\%. Dari table tersebut terlihat bahwa karyawan cukup memiliki pengalaman di bidangnya dan menekuni pekerjaan dengan waktu yang cukup mendukung hasil kerja. Perusahaan setidaknya telah memiliki investasi dari pengetahuan dan pengalaman karyawan selama waktu tersebut.

\subsection{Uji Validitas}

Batas untuk uji validitas adalah pengamatan terhadap nilai dari factor loading $\geq 0,3$. Hasil yang didapatkan dapat dilihat pada Tabel 3 berikut ini. 
Tabel 3. Uji Validitas

\begin{tabular}{|c|c|c|c|c|}
\hline No & Variabel & Topik Pernyataan & $\begin{array}{l}\text { Corrected item- } \\
\text { total correlation }\end{array}$ & Status \\
\hline \multirow[t]{7}{*}{1.} & \multirow{7}{*}{$\begin{array}{c}\text { Pengawasan } \\
\text { Kerja } \\
\text { (X.1) }\end{array}$} & Efektivitas kegiatan pengawasan & 0,576 & Valid \\
\hline & & Pengawasan untuk menekan kesalahan kerja & 0,520 & Valid \\
\hline & & Karyawan terkendali dalam pekerjaan & 0,403 & Valid \\
\hline & & Dampak pengawasan terhadap kualitas kerja & 0,666 & Valid \\
\hline & & Umpan balik dari atasan & 0,482 & Valid \\
\hline & & Aplikasi pengawasan di tempat kerja & 0,555 & Valid \\
\hline & & Tanggapan karyawan terhadap pengawasan & 0,613 & Valid \\
\hline \multirow[t]{5}{*}{2.} & \multirow{5}{*}{$\begin{array}{l}\text { Pengalaman } \\
\text { Kerja } \\
\text { (X.2) }\end{array}$} & Waktu pengerjaan tugas & 0,752 & Valid \\
\hline & & Perbandingan terhadap kualitas kerja & 0,726 & Valid \\
\hline & & Masa kerja & 0,785 & Valid \\
\hline & & Pengetahuan tentang seluk beluk pekerjaan & 0,643 & Valid \\
\hline & & Keterampilan yang lebih baik & 0,566 & Valid \\
\hline \multirow[t]{6}{*}{3.} & \multirow{6}{*}{$\begin{array}{c}\text { Kemampuan } \\
\text { Kerja } \\
\text { (X.3) }\end{array}$} & Kemampuan berinteraksi dengan rekan kerja & 0,755 & Valid \\
\hline & & Kemampuan bekerja sama & 0,765 & Valid \\
\hline & & Kemampuan merencanakan & 0,774 & Valid \\
\hline & & Pemenuhan standar kerja & 0,564 & Valid \\
\hline & & Pengembangan diri & 0,622 & Valid \\
\hline & & Kemandirian menyelesaikan pekerjaan & 0,476 & Valid \\
\hline \multirow[t]{5}{*}{4.} & Motivasi & Berorientasi pada hasil kerja & 0,564 & Valid \\
\hline & \multirow{4}{*}{$\begin{array}{l}\text { Berprestasi } \\
\text { (Y) }\end{array}$} & Fokus pada menyelesaikan tugas & 0,526 & Valid \\
\hline & & Keinginan menjadi yang terbaik & 0,320 & Valid \\
\hline & & Keinginan melampaui atasan & 0,342 & Valid \\
\hline & & Bersikap profesional tanpa empati & 0,421 & Valid \\
\hline
\end{tabular}

Sumber : output SPSS, diolah penulis 2020

Berdasarkan Tabel 3 dinyatakan semua item pernyataan yang diberikan pada karyawan dengan hasil corrected item-total correlation lebih dari 0,3. Maka dari hasil tersebut seluruh pertanyaan dinyatakan valid.

\subsection{Uji Reliabilitas}

Nilai tingkat keandalan (reliabilitas) dilihat dari nilai cronbach's alpha.

Ketentuannya nilai cronbach alpha > 0,6 untuk dinyatakan reliabel.

Tabel 4. Uji Reliabilitas

\begin{tabular}{llcl}
\hline No. & Variabel & cronbach's alpha & Status \\
\hline 1. & Pengawasan Kerja (X.1) & 0,702 & Reliabel \\
\hline 2. & Pengalaman Kerja (X.2) & 0,765 & Reliabel \\
\hline 3. & Kemampuan Kerja (X.3) & 0,762 & Reliabel \\
\hline 4. & Motivasi Berprestasi (Y) & 0,645 & Reliabel \\
\hline
\end{tabular}

Sumber : output SPSS, diolah penulis 2020

Berdasarkan Tabel 4, variabel bebas yaitu pengawasan kerja, pengalaman kerja, kemampuan kerja dan motivasi berprestasi memiliki cronbach alpha > 0,6. 
Dari hasil tersebut diperoleh hasil yang reliabel untuk seluruh variabel. Menurut Hair et al. (2010), rentang 0,61- 0,80 dapat dikatakan reliabel.

\subsection{Uji Asumsi Klasik}

Uji normalitas dianalisis berdasarkan normal P-P Plot. Pada Gambar 2 terlihat penyebaran titik berada di sekitar garis diagonal. Dengan demikian model regresi telah memenuhi asumsi normalitas.

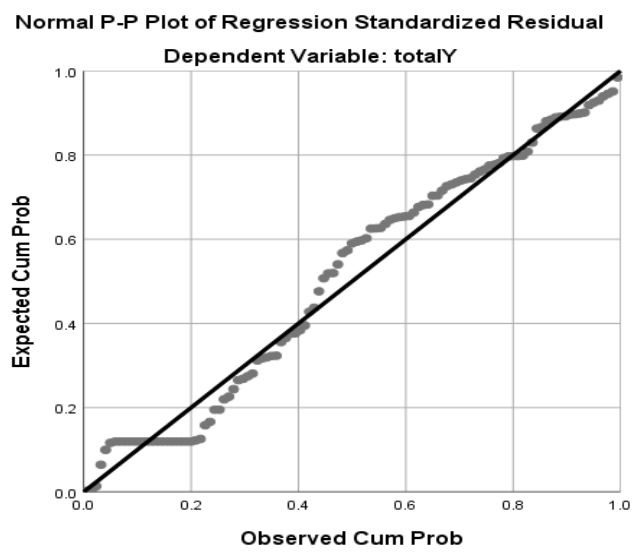

Gambar 2. Uji Normalitas Sumber : output SPSS

Uji autokorelasi berdasarkan nilai Durbin Watson (DW) dengan nilai 1,565. Hal tersebut membuktikan tidak terjadi autokorelasi.

Uji multikolinieritas berdasarkan pada nilai Tolerance value $>0,10$ dan VIF (VarianceInFlatingFactor) $<$ 10. Berdasarkan Tabel 5 nilai VIF untuk variabel bebas kurang dari 10 dan nilai tolerance lebih besar dari 0,1. Hal ini menunjukkan tidak ada masalah multikolinieritas.

Tabel 5. Uji Multikolinieritas

\begin{tabular}{ccc}
\hline Model & \multicolumn{2}{c}{ Collinearity Statistics } \\
\cline { 2 - 3 } & Tolerance & VIF \\
\hline Pengawasan Kerja (X.1) & 0,417 & 2.449 \\
\hline Pengalaman Kerja (X.2) & 0,254 & 3.351 \\
\hline Kemampuan Kerja (X.3) & 0,256 & 3.844
\end{tabular}

Sumber : output SPSS, diolah penulis 2020

Hasil uji heterokedastisitas memperlihatkan tidak ada pola secara jelas. Sebaran titik ada di bawah angka tiga pada sumbu Y yang memperlihatkan model regresi tidak ada gejala heteroskedastisitas. Model regresi tidak mengalami 
gangguan terhadap hal tersebut.

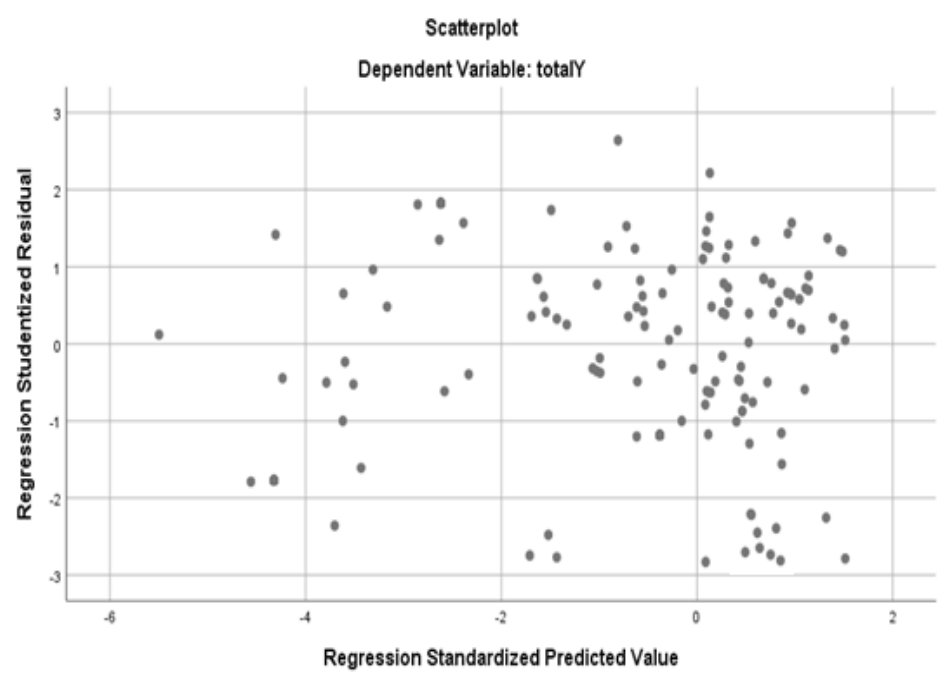

Gambar 3. Scatterplot Dependent Variable Sumber : output SPSS

\subsection{Uji Hipotesis}

Tabel 6 merupakan hasil uji t. Dari tabel tersebut diketahui bahwa secara parsial variabel pengawasan kerja (X.1), pengalaman kerja (X.2) dan kemampuan kerja (X.3) memiliki peran secara nyata terhadap motivasi berprestasi karyawan. Hal ini karena p-value kurang dari 0,05. Didapat persamaan regresi sebagai berikut: $\mathrm{Y}=1,721+0,506 \mathrm{X} .1+0,431 \mathrm{X} .2+0,299 \mathrm{X} .3$.

Tabel 6. Uji t

\begin{tabular}{|c|c|c|c|c|c|c|}
\hline \multicolumn{2}{|c|}{ Model } & \multicolumn{2}{|c|}{$\begin{array}{l}\text { Unstandardized } \\
\text { Coefficients }\end{array}$} & \multirow{2}{*}{$\begin{array}{l}\text { Standardized } \\
\text { Coefficients } \\
\text { Beta }\end{array}$} & \multirow[t]{2}{*}{$\mathrm{t}$} & \multirow[t]{2}{*}{ Sig. } \\
\hline & & B & Std. Error & & & \\
\hline \multirow[t]{4}{*}{1} & (Constant) & 1.721 & 3.562 & & .318 & .731 \\
\hline & X.1 & .506 & .104 & .830 & 2.421 & .018 \\
\hline & X.2 & .431 & .182 & .714 & 2.365 & .024 \\
\hline & X.3 & .299 & .155 & .666 & 2.241 & .025 \\
\hline
\end{tabular}

Sumber : output SPSS

Tabel 6 merupakan uji F. Output SPSS menunjukkan p-value kurang dari 0,05. Dengan demikian variabel pengawasan kerja, pengalaman kerja dan kemampuan kerja secara simultan memiliki peran secara nyata terhadap motivasi berprestasi karyawan. 
Tabel 7. Uji F

\begin{tabular}{llrrrrc}
\hline & Model & Sum of Squares & \multicolumn{1}{c}{ df } & Mean Square & F & \multicolumn{1}{c}{ Sig. } \\
\hline 1 & Regresion & 1595.131 & 3 & 565.267 & 19.201 & $0,000^{\mathrm{b}}$ \\
\cline { 2 - 7 } & Residual & 3176.200 & 117 & 29.212 & & \\
\cline { 2 - 7 } & Total & 4771.331 & 120 & & & \\
\hline
\end{tabular}

Sumber : output SPSS

Tabel 7 menunjukkan nilai koefesien determinasi sebesar 0,328 atau 32,8\%. Angka ini berarti variabel pengawasan kerja, pengalaman kerja, dan kemampuan kerja memberikan kontribusi 32,8\% terbentuknya variabel motivasi berprestasi sedangkan sisanya $62,2 \%$ dijelaskan oleh sebab-sebab yang lain di luar penelitian ini.

Tabel 8. Koefisien Determinasi

\begin{tabular}{crrrr}
\hline Model & R & R Square & Adjusted R Square & Std. Error of the Estimate \\
\hline 1 & $0,587^{\mathrm{a}}$ & 0,346 & 0,328 & 5,40328
\end{tabular}

Sumber : output SPSS

\subsection{Pembahasan}

Pada uji hipotesis terlihat bahwa variabel pengawasan kerja memiliki peran positif secara nyata terhadap motivasi berprestasi. Hal tersebut mengindikasikan bahwa pengawasan kerja berperan untuk meningkatkan motivasi berprestasi karyawan. Sejalan dengan penelitian sebelumnya yang telah dilakukan oleh Ekowati (2012) yang mengatakan bahwa pengawasan kerja memiliki pengaruh positif secara nyata terhadap motivasi kerja, apabila pengawasan kerja baik maka motivasi kerja juga akan baik. Penelitian dari Awaliyah et al. (2019) menyatakan bahwa pengawasan yang didukung oleh kompetensi secara profesional memiliki pengaruh terhadap prestasi kerja sumber daya manusia. Sedangkan studi dari Renata et al. (2018) pengawasan kerja dan motivasi berprestasi mengarahkan kepada efektivitas kerja di organisasi. Selain itu Putra et al., (2017) menyebut pengawasan kerja akan memberikan dampak yang signifikan terhadap produktivitas kerja. Sivakumar (2016) menyatakan bahwa motivasi berprestasi terbentuk dari salah satu kontribusi variabel pengawasan kerja yang memiliki sistem yang tepat dan berhasil mengarahkan perilaku kerja para karyawan. Beberapa studi tersebut memperjelas bahwa pengawasan perlu dilakukan agar 
kondisi ideal yang diharapkan organisasi dapat terwujud dan salah satunya adalah para karyawan memiliki motivasi berprestasi untuk memberikan keberhasilan dalam pekerjaan (Darmawan, 2008).

Hipotesis lainnya menyebutkan bahwa pengalaman kerja memiliki peran positif secara nyata terhadap motivasi berprestasi. Hal ini sejalan dengan penelitian yang dilakukan oleh Handayani (2010) yang mengatakan bahwa pengalaman kerja memiliki peran secara nyata terhadap motivasi kerja karyawan. Dimana jelas bahwa karyawan yang telah memiliki pengalaman kerja mampu untuk termotivasi memberikan hasil terbaik mereka dalam bekerja dan hal tesebut menunjukkan kedewasaan dalam pekerjaan mereka. Menurut Haasen dan Shea (1979), beberapa orang suka mencoba pengalaman baru dan menetapkan tujuan yang lebih menantang, yang lain lebih suka tetap berada di zona nyaman dan senang dengan apa yang mereka tahu bisa mereka capai. Tapi itu semua berdasarkan pandangan terhadap diri kita sendiri. Alderman (1999) menyatakan pengalaman pribadi adalah salah satu sumber informasi yang efektif dan yang paling berpengaruh. Ini mengikuti kemudian bahwa kesuksesan cenderung meningkatkan ekspektasi keberhasilan sedangkan kegagalan cenderung menurunkannya. Latta (1974) berpendapat bahwa upaya yang dimaksudkan dari tugas juga berperan dalam motivasi berprestasi. Jika individu memiliki pengalaman atau kemampuan terkait dalam melakukan tugas, jumlah upaya yang dimaksudkan untuk menyelesaikan tugas akan rendah, dan peluang untuk hasil yang positif meningkat. Alderman (1999) memperkuat bahwa seseorang lebih cenderung melakukan tugas yang diyakini memiliki keterampilan untuk ditangani, tetapi menghindari tugas yang diyakini membutuhkan keterampilan yang lebih besar daripada yang dimiliki. Latta (1974) melanjutkan bahwa jika individu tidak memiliki pengalaman atau kemampuan, maka usaha yang diinginkan besar, dan peluang untuk hasil yang positif berkurang. Seseorang yang gagal dalam suatu tugas akan menghubungkan pada harapan untuk sukses di masa depan berbeda tergantung pada apakah menghubungkan kegagalan dengan kurangnya usaha (mencoba) atau tidak memiliki kemampuan (dapat) untuk berhasil dalam tugas. Meski demikian apa yang terjadi pada proses mental di masing-masing diri karyawan, seharusnya terpantau 
oleh para pemimpin dalam hal ini supervisor (Karina et al., 2012). Pemimpin seharusnya lebih mudah mendorong para karyawan yang berpengalaman dengan dukungan pengawasan yang tepat (Oetomo dan Darmawan, 2004).

Hipotesis selanjutnya menyebutkan bahwa kemampuan kerja memiliki peran positif secara nyata terhadap motivasi berprestasi karyawan. Menurut Apriani (2009), faktor kemampuan kerja bukan hanya akan memengaruhi kinerja karyawan tetapi mendorong mereka untuk memberikan prestasi kerja yang terbaik. Karyawan yang memiliki kemampuan kerja terdorong untuk terus mengembangkan potensi diri dan kemampuan kerja bila didukung dengan kondisi kerja yang kondusif serta imbalan yang sesuai harapan mereka (Darmawan, 2007; Sinambela, 2020). Kemampuan yang menunjukkan kualitas sumber daya manusia, pada akhirnya menggiring kepada terbentuknya kesetiaan karyawan terhadap perusahaan karena kesesuaian kemampuan mereka dengan merasa berguna bagi perwujudan tujuan perusahaan (Mardikaningsih, 2016; Darmawan et al., 2020).

\section{Kesimpulan}

Kesimpulan ini didasari oleh hasil yang telah didapatkan dan pembahasan yang sebelumnya telah dilakukan, maka hasil kesimpulannya adalah (1) pengawasan kerja benar-benar memiliki peran secara nyata terhadap motivasi berprestasi (2) pengalaman kerja benar-benar memiliki peran secara nyata terhadap motivasi berprestasi (3) kemampuan kerja benar-benar memiliki peran secara nyata terhadap motivasi berprestasi (4) pengawasan kerja, pengalaman kerja, dan kemampuan kerja benar-benar memiliki peran nyata secara simultan terhadap motivasi berprestasi.

Hasil ini merekomendasikan bentuk implikasi manajerial yang dapat diambil bahwa adanya pengawasan pada saat bekerja berpengaruh terhadap perilaku kerja. Karyawan menjadi termotivasi bekerja di bawah sebuah tekanan ataupun aturan. Didukung pengalaman kerja yang baik mendorong karyawan untuk meningkatkan prestasinya. Kemampuan yang dibentuk dari pengalaman kerja akan memberikan hasil yang maksimal terhadap pekerjaannya. Perusahaan dapat menggunakan cara pelatihan dan workshop karyawan. Pelatihan yang diberikan juga harus tepat dan 
sesuai dengan kondisi karyawan sehingga memberikan rasa percaya diri, menambah motivasi. Perusahaan harus memastikan bahwa telah menghargai hasil pekerjaan karyawannya karena dengan hal tesebut karyawan merasa memiliki peran yang penting sehingga berkeinginan untuk meningkatkan prestasinya di tempat kerja. Selanjutnya melakukan analisis kesesuaian antara pekerjaan yang akan dilakukan dengan pendidikan, pengalaman, kemampuan setiap karyawannya. Perusahaan yang mampu menyesuaikan kondisi tersebut, maka telah memposisikan karyawannya dengan tepat sehingga berpotensi untuk meningkatkan motivasi kerja karyawan. Bagi akademisi, penelitian ini dapat menjadi wacana ataupun sumber referensi. Untuk penelitian lebih mendalam dapat menambahkan variabel-variabel lain yang relevan dengan kehidupan di perusahaan dan pengembangannya.

\section{DAFTAR PUSTAKA}

Al Hakim, Y. R., M. Irfan, R. Mardikaningsih, E. A. Sinambela. (2019). Peranan Hubungan Kerja, Pengembangan Karir, dan Motivasi Kerja terhadap Kepuasan Kerja Karyawan, Management \& Accounting Research Journal, Vol.3 No.2, 3745

Alderman, M. (1999). Motivation for achievement: Possibilities for teaching and learning. New Jersey: Lawrence Erlbaum Associates, Inc., Publishers.

Andayani, D., S. Kabalmay, R. Resandi, D. Darmawan. (2010). Pemberdayaan Karyawan Berbasis Keunggulan Bersaing, IntiPresindo Pustaka, Bandung.

Atkinson, J. W., \& Feather, N. T. (1966). A Theory of Achievement Motivation. Wiley: New York.

Atkinson, J. (1974). Motivation and achievement. Washington, D. C.: V. H. Winston and Sons.

Apriani, Fajar. (2009). Pengaruh Kompetensi Motivasi dan Kepemimpinan terhadap Kinerja Bisnis dan Birokrasi. Jurnal Ilmu Administrasi dan Organisasi, Vol. 16, No.1, 13-17.

Awaliyah, R., Rusdinal, \& Yahya. (2019). Contribution Of Professional Competence and Supervision Toward Vocational High School Teacher S' Performance in Lima Puluh Kota District. International Journal of Educational Dynamics, 1(2), 325-333.

Biegge, M.O., \& Hunt, Y. B. (1980). Intrapersonal and Interpersonal Theories of Motivation from an Attributional Perspektif. Educational Psychology Review, Vol. 12, No. 1, pp. 1-14.

Berenson, M. L., Levine, D.M. \& Krehbiel, T.C. (2012). Basic Business Statistics: Concept and Application. $12^{\text {th }}$ ed. Sydney: Prentice Hall.

Blumberg, B., Cooper, D. R., \& Schindler, P. S. (2005). Business Research Methods 
Berkshire: McGrawHill Education.

Chakrabartty, S. N. (2013). Best Split-Half and Maximum Reliability. IOSR Journal of Research \& Method in Education, Vol. 3, Issue 1, 1-8.

Chiovere, B. R. (1995). Educational Administration and Management. Harare: Mazongororo Paper converters Ltd.

Durotolu, A.O. (2002). Educational management: An introduction. $2^{\text {nd }}$ ed. Ilorin: Mercy Prints.

Draper, N. R. \& Smith, H. (1998). Applied Regression Analysis. $3^{\text {th }}$ ed. New York: John Wiley and sons, Inc.

Darmawan, D. (2007). Strategi Pengembangan Sumber Daya Manusia, Pustakamedia Daya, Bandung.

Darmawan, D. (2008). Teori Motivasi, Surabaya: Metromedia.

Darmawan, D. (2013). Prinsip-Prinsip Perilaku Organisasi. Surabaya: Pena Semesta.

Darmawan, D. (2015). Metodologi Penelitian. Surabaya: Metromedia.

Darmawan, D. (2017). Pemberdayaan Kerjasama, Surabaya: Metromedia.

Darmawan, D. (2019). Profesionalisme, Motivasi Berprestasi, Komitmen Organisasi dan Pengaruhnya terhadap Intensi Berwirausaha Ekuitas, Jurnal Ekonomi dan Keuangan, Vol. 3, No. 3 September, 344-364

Darmawan, D., S. Arifin, R. Mardikaningsih, Moch. Irfan. (2019). Pengaruh Pendidikan, Kemampuan Kerja dan Pengalaman Kerja terhadap Kinerja Karyawan, Jurnal Ekonomi Bisnis, Vol.12 No.1, 35-47.

Darmawan, D., et al. (2020). The Quality of Human Resources, Job Performance and Employee Loyalty, International Journal of Psychosocial Rehabilitation, Vol. 24 Issue 3, 2580-2592.

Dave, P. N., \& Anand, C. L. (1979). Correlates of Achievement: a trend report, in M. B. Buch (ed.). $2^{\text {nd }}$ Survey of Research in Education, SERD: Baroda, 331.

Dessler, Gary. (2009). Human Resources Management. Jakarta: The Index.

Djati, S. Pantja \& D. Darmawan. (2005). Pengaruh Kinerja Karyawan terhadap Kepuasan, Kepercayaan, dan Kesetiaan Pelanggan, Jurnal Manajemen dan Kewirausahaan, Vol.7 No.1 Maret, 48-59.

Elliot. A.J., Mc Gregor, H.A., Cambell, W.F., Sedikes, C., \& Harackiewicz, J.M. (2000). Competence Valuation as a strategic intrinsic motivation prosses. Journal of Personality and Social Psychology, 26(7), 780-790.

Enaigbe, A. P. (2009). Strategies for Improving Supervisory Skills for Effective Primary Education in Nigeria. Edo Journal of Counselling, Vol. 2, No. 2, pp. 236-241.

Ekowati, R, E. (2012). Hubungan Persepsi Tentang Supervisi Kepala Sekolah dan Motivasi Berprestasi Terhadap Kinerja Mengajar Guru SMK RSBI di Daerah Istemewa Yogyakarta. Skripsi: Universitas Negeri Yogyakarta.

Foster, Bill. (2001). Pembinaan Untuk Peningkatan Kinerja Karyawan. Jakarta: PPM. 
Gibson, James L, John M.I., James H.Donelly., \& Robert K. (2009). Organizational Behaviour, Structure, Procsses. $14^{\text {th }}$ ed. New York: Mc Graw Hill Education.

Ghasemi, F., Rastegar, A., Jahromi, R. G., \& Marvdashti, R. R. (2011). The Relationship Between Creativity and Achievement Motivation with High School Student'Enterpreneurship. Social and Behavioral Sciences, Vol. 30, 1291-1296.

Gujarati, Damodar N. (2003). Basic Economics. Singapore: Prentice Hall Inc.

Haasen, A. \& Shea, G. (1979). A better place to work: A new sense of motivation leading to high productivity. New York, NY: AMA Membership Publications Division.

Handayani, Lestari. (2010). Pengaruh Tingkat Pendidikan dan Pengalaman Kerja Terhadap Motivasi Kerja Karyawan Bagian Produksi pada CV. Trubus Prima di Gemolong. Skripsi: Universitas Muhammadiyah Surakarta.

Handoko, V. Rudy. \& D. Darmawan. (2004). Pengaruh Kinerja Wiraniaga dan Karakter Demografinya terhadap Kinerja Pasar Perusahaan, Jurnal Ilmu-Ilmu Sosial dan Humaniora, Vol.8 No.1 Juli, 63-72.

Hair, J. F. Jr., William, C.B., Banin, B. J., \& Anderson, R. E. (2010). Multivariate Data Analysis. $7^{\text {th }}$ ed. New Jersey: Upper Saddle River-Prentice Hall.

Hariani, Mila., Samsul Arifin, Arif Rahman Putra. 2019. Pengaruh Iklim Organisasi, Pengalaman Kerja dan Motivasi Kerja terhadap Komitmen Kerja Karyawan, Management \& Accounting Research Journal, Vol.3 No.2 Mei, 2228.

Helmreich, R. L., dan Spence, J. T. (1978). The Work and Family Orientation Questionnaire: An objective instrument to assess components of achievement motivation and attitudes toward family and career. Journal Supplement Abstract Service, Catalog of Selected Documents in Psychology, Vol. 8, p.35.

Hutomo, S. \& D. Darmawan. (2011). Optimalisasi Manajemen Sumber Daya Manusia Menuju Keunggulan Bersaing, Jurnal Ilmu Sosial, Vol. 5, No. 1, 1322.

Ilmarinen J. (2004). Towards a Longer Worklife: Ageing and the quality of worklife in the European Union. Finnish Institute of Occupational Health: Ministry of Social Affairs and Health.

Jagacinski, \& C., Duda, J. (2001). A comparative analysis of contemporary achievement goal orientation measures. Education and Psychological Measurement, 61(6), 1013-1039.

Johnson, P. E. (2000). Skilled supervisor is interpersonal: A response to Duncan Waite. Int. J. Educ. Reform. 9(4), 292-297.

Karina, Ana., T. Baskoro K. \& D. Darmawan. (2012). Pengantar Psikologi, Addar Press, Jakarta.

Khasanah, Hikmahtul, Setya Arum, D. Darmawan. (2010). Pengantar Manajemen Bisnis, Spektrum Nusa Press, Jakarta.

Latta, R. (1974). The influence of achievement motivation, success, and intended effort on behavioral intensity. Iowa City. IA: Midwestern Psychological 
Association Annual Meeting. (ERIC Document Reproduction Service Number ED 095 461).

Mardikaningsih, R. (2014). Kinerja Karyawan dan Faktor-Faktor yang memengaruhinya, Jurnal Ilmu Sosial, Vol. 7, No. 2, 73-84.

Mardikaningsih, R. (2016). Variabel Kepemimpinan dan Lingkungan Kerja serta Pengaruhnya terhadap Kinerja Karyawan, Management \& Accounting Research Journal, Vol.1 No.1 November, 55-62.

Mardikaningsih, R., S. Arifin, A. R. Putra, \& M. Hariani. (2017). The Effect of Motivation and Work Commitment on The Performance of Agricultural Extension Agents, Jurnal Agrimas, Vol.1 No.2 Desember, 115-124.

Mc Clelland, D.C. (1987). Human Motivation. Melbourne: Cambigde University Press.

Mathis, R.L. \& Jackson, J.H. (2006). Human Resource Management. Jakarta: Salemba Empat.

Nurmalia ria. (2012). Pengaruh Pengawasan oleh Pemimpin terhadap Kinerja Pegawai Ispektorat Daerah Kabupaten Bandung. Skripsi: UPI Bandung.

Oetomo, Hasan \& D. Darmawan. (2004). Pengaruh Aspek Pendidikan, Pelatihan, Umur dan Pengalaman Kerja terhadap Perilaku Gaya Kepemimpinan, Jurnal Ekonomi-Manajemen, Vol.3 No.2 Desember, 11-22.

Pallant, J. (2011). A Step by Step Guide to Data Analysis Using the SPSS Program: Survival Manual. $4^{\text {th }}$ ed. Berkshire: McGraw-Hill.

Pearce, Nathalie., Helen Beinart, Sue Clohessy \& Myra Cooper. (2013). Development and Validation of the Supervisory Relationship Measure: A SelfReport Questionnaire for Use with Supervisors, British Journal of Clinical Psychology, Vol. 52, 249-268.

Pintrich P. R., \& Shunk D. H. (1996). Motivation in Education: Theory, Research and Aplications. Englewood Cliffs, NJ: Prentice Hall.

Putra, A. R., D. Darmawan, E. A. S. (2017). Pengawasan dan Koordinasi Kerja serta Pengaruhnya terhadap Produktivitas Kerja Karyawan, Akuntabilitas Jurnal Ilmiah Ilmu-ilmu Ekonomi, Vol. 10, No. 2, 12-24.

Putra, A. R., E. Retnowati \& E. A. Sinambela. (2019). Pengaruh Komunikasi Kerja dan Integritas terhadap Kinerja Pegawai, Ebis, Jurnal Ekonomi Bisnis, Vol. 12 No. 1 Januari, 23-34.

Renata, Wardiah, D., \& Kristiawan, M. (2018). The influence of headmaster's supervision and achievement motivation on effective teachers. International Journal of Scientific and Technology Research, 7(6), 44-49.

Robbins, Stephen P., \& Timothy A. Judge. (2008). Perilaku Organisasi, Edisi 12 Buku 1. Jakarta: Salemba Empat.

Robbins, Stephen P. (1998). Perilaku Organisasi, Edisi Bahasa Indonesia Cetakan Ke 2, Jakarta: Prenhallindo.

Robson, C. (2011). Real World Research: A Resource for Users of Social Research Methods in Applied Settings. $2^{\text {nd }}$ ed. Sussex: A. John Wiley and Sons MaLtd. 
Rabideau, S. T. (2005). Effects of Achievement Motivation on Behaviour. Retrieved

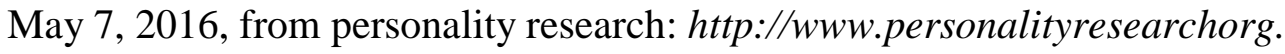

Santosa, A. \& D. Darmawan. (2002). Hubungan Kepemimpinan, Budaya Organisasi dan Kinerja Karyawan, Jurnal Ilmu Manajemen, Vol 3 No 2, 81-92

Schmidt, Frank L., Frank L. Schmidt, John E. Hunter \& Alice N. Outerbridge. (1986). Impact of Job Experience and Ability on Job Knowledge, Work Sample Performance, and Supervisory Ratings of Job Performance, Journal of Applied Psychology, Vol. 71, No. 3, 432-439.

Schmidt, Frank L., Alice N. Outerbridge, John E. Hunter \& Stephen Goff. (1988). Joint Relation of Experience and Ability with Job Performance: Test of Three Hypotheses, Journal of Applied Psychology, Vol. 73, No. 1,46-57.

Schuler, J., Sheldon, K.M., \& Frohlich, S.M. (2010). Implicit need for achievement moderates the relationship between competence need satisfaction and subsequent motivation. Journal of Research in Personality, 44, 1-12.

Sinambela, E. A. (2014). Pengaruh Motivasi, Disiplin dan Lingkungan Kerja terhadap Kepuasan dan Loyailtas Kerja, Jurnal Ilmu Sosial, Vol. 7, No. 3, 123136.

Sinambela, E. A., D. Darmawan \& M. Hariani. (2018). Dasar Dasar Manajemen Sumber Daya Manusia, Metromedia, Surabaya.

Sinambela, E. A., D. Darmawan, M. Hariani \& M. Irfan. (2020). Analisis Komitmen Organisasi, Iklim Kerja, Kepuasan Kerja dan Etos Kerja yang Memengaruhi Kinerja Pegawai, Jurnal Bisnis dan Kajian Strategi Manajemen, Vol. 4 No. 1, 58-70.

Sinambela, E. A., R. Mardikaningsih, S. Arifin, H. DyahAyu. (2020). Development of Self Competence and Supervision to Achieve Professionalism, Journal of Islamic Economics Perspectives, Vol. 1. No. 2, 33-42.

Sivakumar, R. (2016). Achievement Motivation of Teacher Trainees in Colleges of Education. Journal of Contemporary Educational Research and Innovations, 6(5), 180-186.

Sjamsi, N. \& D. Darmawan. (2004). Peran Startegis Layanan pada Penyelenggaraan Pelayanan Publik, Jurnal Administrasi Publik, Vol.1 No.1 Desember, 83-95.

Stewart, K. G. (2005). Introduction to Applied Econometrics. Cole Belmont, CA: Thomson Brooks.

Sparrow. (1998). Achievement and Motivation, University of Sheffield Management School, UK: 639-663.

Wagner, M., Powers, S., \& Irwin, P. (1985). The prediction of achievement motivation using performance and attributional variables. Journal of Psychology, 119(6), 595-598.

Wahyudi, I., D. Bhaskara, D. Darmawan, Hermawan \& N. Damayanti. (2006). Kinerja Organisasi dan Faktor-Faktor Pembentuknya, Jurnal Ekonomi dan Bisnis, Volume 4 Nomor 2, November, 95-108. 
Werdati, F., D. Darmawan \& N. R. Solihah. 2020. The Role of Remuneration Contribution and Social Support in Organizational Life to Build Work Engagement, Journal of Islamic Economics Perspectives, Vol 1 No 2, 20-32.

Weseley, A. J., \& McEntarffer, R. (2010). Barron's AP Psychology. $4^{\text {th }}$ ed. New York: Barron's Educational Series, Inc. 